\title{
Dette må du vite om biofilm
}

De fleste ikke-helende sår er dekket av bakteriell biofilm. Det må vi ta hensyn til når vi velger behandlingsstrategier.

\section{Forfattere}

Arne Langøen

Dosent

Institutt for helse- og omsorgsvitskap, Høgskulen på Vestlandet

Marcus Gürgen

Allmennlege i spesialisering og overlege

Kvinesdal legesenter og Kirurgisk avdeling, Sørlandet sykehus, Flekkefjord

Hud Kirurgi Sår sårbehandling Biofilm

Sykepleien 2019 107(74753)(e-74753)

DOI: https://doi.org/10.4220/Sykepleiens.2019.74753

\section{Hovedbudskap}

Vi må aktivt bekjempe bakteriene for å få sår til å gro. De metodene vi tidligere benyttet, som bakterieprøve, behandling med antiobiotika eller lokale antibakterielle midler, har endret seg de siste årene. Informasjonen fra bakterieprøver som penselprøver samt virkningen av antibiotika ved lokale infeksjoner i sår har vist seg å være svært begrenset. Vi må bruke ny kunnskap om hvordan vi kan bekjempe bakterier i biofilm, og betydningen av konsekvent behandling er helt avgjørende for å få ikke-helende sår til å gro. 
Kunnskapen om bakterienes påvirkning på sårheling har økt voldsomt de siste ti årene. Det skyldes at vi har fått tilgang til nye teknikker for å studere bakterier, som PCR (Polymerase Chain Reaction) og M-FISH (Multiplex fluorescence in situ hybridization). Disse teknikkene har gjort det mulig å forstå bedre hva som skjer i ikke-helende sår, og de gir et klarere bilde av bakterienes rolle (1).

Da kunnskapen om sårbehandling først ble satt i system i Norge som et resultat av dannelsen av NIFS (Norsk interessefaggruppe for sårheling), rådet følgende, ene «sannhet»: Forutsetningen for at et sår skal gro, er at det kommer nok oksygenrikt blod til det området såret befinner seg. Det ble kommunisert på møter, konferanser og forelesninger at oksygenrikt blod var det eneste som kunne få sår til å gro.

Sagt på en enkel måte: Behandlingen var karkirurgi ved sviktende arteriell sirkulasjon, og kompresjonsbehandling ved venøs insuffisiens. Påstanden er for så vidt riktig, men ikke lenger den eneste forklaringen.

\section{Ulike typer sår}

Alle som jobber med ikke-helende sår, vet at sår i områder på kroppen som både er godt sirkulert og har tilfredsstillende ødembehandling, likevel kan være vanskelige å få til å gro. Dermed må det være flere forklaringer på at sår ikke gror.

I 2003 kom det en artikkel i tidsskriftet Wound Repair and Regeneration som forklarte noe om betydningen av lokalbehandling av sår (2). Den så på forskjellen mellom akutte sår og ikke-helende sår og diskuterte i hvilken grad lokale forhold i såret hadde betydning for om såret helet eller ikke.

Forfatterne fokuserte videre på bakteriers betydning $\mathrm{i}$ ikke-helende sår. De laget følgende oversikt over sammenhengen mellom bakterier og sårheling: 
- Kontaminerte sår, det vil si sår som er forurenset, har ingen betydning for sårhelingen.

- Koloniserte sår, sår der bakterier er etablert og formerer seg, har fortsatt ingen klar betydning for sårhelingen.

- Kritisk koloniserte sår var et nytt begrep forskerne innførte, som beskriver en tilstand der bakteriene hemmer sårhelingen.

- Infiserte sår, som er sår der det foreligger en infeksjon med allmennsymptomer og stigning av CRP eller hvite blodlegemer, har ingen sårheling. Problemet med artikkelen deres var at de ikke kunne forklare godt hva kritisk koloniserte sår var. De laget en diffus definisjon der antall bakterier var større enn 105 per gram vev (2).

\section{Betydningen av biofilm}

I 2008 og utover på 2000-tallet kom det flere artikler i Journal of Wound Care der begrepet bakteriell biofilm ble presentert og tillagt betydelig ansvar for at sår ikke heler (3-5).

Grunnlaget til artiklene baserte seg på in vitroforskning, forskning i et laboratorium, om hvordan bakterier samvirker og organiserer seg. Imidlertid har det vist seg å være vanskelig å definere bakteriell biofilm i sår, da den opptrer annerledes i klinikken enn på laboratoriet.

\section{Hva er biofilm?}

Den klassiske definisjonen på biofilm er som følger (1): «Bacteria attached to surface, encapsulated in a self-produced extracellular matrix and tolerant to antimicrobial agents», altså bakterier som sitter fast til underlaget og er dekket av en selvprodusert matriks (nettverk av fiberdannende proteiner og polysakkarider i vevet rundt cellene) som gjør dem motstandsdyktige mot antibakterielle midler (1). 


\section{三 «Bakterien lar seg ikke eliminere med vanlige antimikrobielle strategier.»}

Denne definisjonen passer ikke på biofilm i sår. Senere forskning viser at bakteriene i sårmiljøet ikke er avhengige av flater for å feste seg. Forskningen viser dessuten at matriksen består av stoffer bakteriene har tilgjengelige i sårmiljøet. Bakterien lar seg ikke eliminere med vanlige antimikrobielle strategier.

Derfor har WUWHS (World Union of Wound Healing Societies) valgt følgende definisjon på biofilm i ikkehelende sår: «an aggregate of bacteria tolerant to treatment and host defence» (1). Det sentrale er altså at bakterier som er dekket av biofilm, hindrer såret i å gro og er motstandsdyktige både mot antibakterielle midler, inklusiv antibiotika, og kroppens forsvarsmekanismer mot bakterier.

\section{Slik virker biofilm}

En metaanalyse anslår at det er bakteriell biofilm i 78,2 prosent av alle ikke-helende sår (6). Det hevdes av andre at alle ikke-helende sår har problemer knyttet til bakteriell biofilm (1). Å forstå biofilmens virkning i sår er derfor ensbetydende med å forstå hvordan ikkehelende sår skal behandles.

En detaljert beskrivelse av hvordan bakteriell biofilm hindrer såret i å hele, er utenfor denne artikkelens målsetting, men gode gjennomganger finnes i referansene $(1,6-7)$.

Enkelt sagt ønsker bakteriene å oppnå tre ting med sitt virke i såret (7):

\section{- Unngå å bli drept og fagocytert (eliminert) av} kroppens hvite blodlegemer. Granulocytter og makrofager er kroppens førsteforsvar mot uønskede mikroorganismer. En del sårpatogene mikroorganismer har evnen til å «lure» vertens immunsystem slik at de ikke oppdages av 
forsvarscellene. Deretter dannes den beskyttende matriksen som bakteriene omgir seg med. Denne beskyttelsen dannes dels av bakteriene og dels av kroppens eget materiale.

- Sikre bakteriekoloniene nok næring. Når bakteriene er godt skjult i ekstracellulær matriks, provoserer de verten til å angripe. Vertens forsvar mot bakterier innebærer å øke produksjonen av granulocytter, makrofager og proinflammatoriske cytokiner. Cytokinenes oppgave er blant annet å øke blodsirkulasjon i sårområdet. Bedre tilgang på næring til mikroorganismene er en viktig konsekvens av den økte inflammasjonen.

- Unngå at såret lukker seg. Hvis såret gror, blir bakterienes tilholdssted ødelagt, og bakteriene blir fjernet. Ved å ta livet av granulocyttene som verten sender inn i området, frigir de døde granulocyttene store mengder cytokiner og MMP (matriks metalloproteinaser). For eksempel gjør Pseudomonas-bakteriene dette ved å produsere rhamnolipid, som dreper granulocytter. MMP er potente enzymer som forekommer i økt konsentrasjon i områder med økt cytokinkonsentrasjon. MMP bryter ned kollagen (bindevev som cellene fester seg i) og vekstfaktorer (molekyler som koordinerer celleaktivitet i et sår). Konsekvensene av økt MMP-tilgang i såret er vevsnedbryting, nekrosedannelse, kronisk inflammasjon og til sjuende og sist manglende sårheling.

\section{Behandling av sår}

Det er også et annet forhold som har betydning for hvordan vi skal behandle sår med biofilm. Inne i biofilmen går bakteriene over i en form for dvaletilstand. De senker sin metabolisme nesten ned til null. Bakteriene blir da nærmest umulige å skade, både fra immunsystemets side, men også fra antibakterielle strategier (4). 


\section{三 «Det viser seg at både systemisk antibiotika og lokale antibakterielle midler er uten effekt på bakterier inne i en intakt biofilm.»}

Det viser seg at både systemisk antibiotika og lokale antibakterielle midler er uten effekt på bakterier inne i en intakt biofilm (8). Men hvis biofilmen skades, for eksempel ved hjelp av debridering (fjerning av dødt, skadet eller infisert vev), må bakteriene «jobbe» og reparere skaden. Det vil si at de må bli metabolsk aktive, og de er dermed mulige å elimineres fra sår (9).

\section{Må skade biofilmen}

Vi har lenge håpet at det skulle komme et «vidundermiddel» som løser opp matriksen som bakteriene omgir seg med, og som gjør dem tilgjengelige for antibakterielle midler. En slik løsning er ikke kommet, til tross for at det er gjort intense forsøk.

Men det viser seg at dersom vi klarer å skade biofilmen ved hjelp av en eller annen form for debridering, så har lokale antiseptiske midler effekt. Debridering fører til at matriksen påføres skader, men den fjernes ikke. Biofilmen gir dermed ikke samme beskyttelse.

Minst like viktig er det at bakteriene da blir trigget til å bli metabolsk aktive og dermed sårbare. Det betyr at lokale antiseptiske midler alltid skal benyttes sammen med debridering, og antiseptiske midler uten debridering har en begrenset verdi (1).

Utfordringen blir å finne en debrideringsmetode som både er effektiv og gjennomførbar, det vil si ikke mer komplisert enn at de som behandler såret, er i stand til å utføre den. 


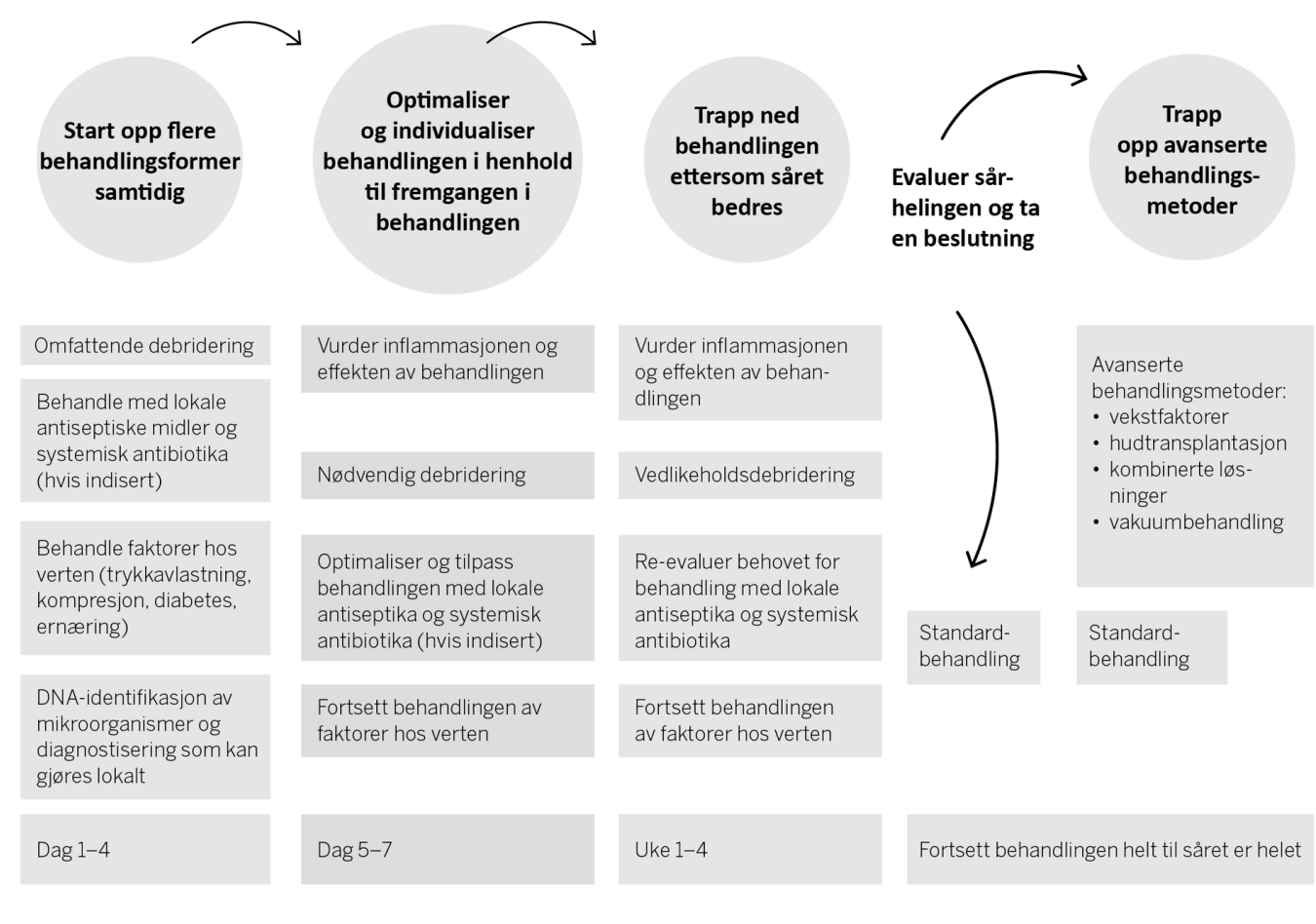

Kilde: Modifisert etter Schultz G, Bjarnsholt T, James GA, Leaper DJ, McBain AJ, Malone M et al. Consensus guidelines for the identification and treatment of biofilms in chronic nonhealing wounds. Wound Repair Regen. 2017;25(5):744-57

\section{Debrideringsmetoder}

Den europeiske sårorganisasjonen EWMA (European

Wound Management Association) laget i 2013 en oppsummering, kalt position document, der de beskrev alternative metoder for debridering (10). De delte debridering inn i følgende metoder:

- Mekanisk debridering. Dette inkluderer bruk av vridde, våte gas- eller bomullskompresser (wet-todry dressings), som tørker i såret og rives ut. Videre er tannbørste, neglebørste og debrideringspad å regne som mekanisk debridering.

- Autolytisk debridering. Da forsterkes kroppens egne debrideringsløsninger ved å holde såret fuktig. Hydrogel, honning, jod og antibakteriell gel virker på denne måten. Det er også mulig at noen av formene for autolytisk debridering har en viss skadelig virkning på bakteriene i biofilmen.

- Biokirurgi. Dette er bruk av fluelarver til rengjøring av sår. Denne løsningen er gammel, men 
har fått sin renessanse (7).

- Tekniske løsninger. På dette området er det de siste årene kommet løsninger som faktisk har debriderende virkning, som vakuumforsegling med periodisk skyll, høytrykksspyling av såret, lavfrekvent ultralyd med skyll, eller plasmabehandling. Felles for disse apparatene er at de er svært dyre i innkjøp og forholdsvis dyre i bruk.

- Skarp debridering. Da benyttes skalpell, kyrette, skarp skje eller saks.

Det er viktig å poengtere at ikke alle metodene er egnet for alle pasienter og alle sår. Noen metoder, som debridering med vridde, våte saltvannskompresser, frarådes fordi de er lite selektive, det vil si at de skader også friskt vev.

\section{Kjemisk debridering}

De siste årene er kjemisk debridering tatt i bruk (9).

Det er tre grupper av løsninger som kan benyttes:

- Løsninger med overflateaktive midler. Slike midler, også kalt tensider, finnes i rengjøringsmidler med lav pH, som sjampo og flytende såper. De fleste sår kan vaskes med flytende såpe og skylles etterpå med rennende vann. Noen sårhjelpemidler og bandasjer inneholder tensider, slik som Prontosan og PolyMem.

- Løsninger basert på syrer. Den syren de fleste har erfaring med, er acetic acid, eller eddiksyre. Denne løsningen har vært benyttet i sårbehandlingen $\mathrm{i}$ hundrevis av år. De siste årene er det kommet kommersielle løsninger der eddik er en bestanddel, slik som SoftOx og Optima. I land som India og Bangladesh gjøres det forsøk med å bruke eddikløsninger i sår fordi det er enkelt, virkningsfullt og billig $(11,12)$. 
- Superoksiderte væsker. Også denne gruppen av produkter er gamle løsninger som har fătt sin renessanse de siste årene. Den mest brukte superoksiderte væsken var tidligere hydrogenperoksid 3 prosent (7). Hydrogenperoksid har sannsynligvis god effekt på bakterier, men kan også ha en uheldig virkning på granulasjonsvev, så den frarådes på dette grunnlaget. Men det er kommet nye og mindre skadelige superoksiderte væsker på markedet, som Microdacyn og SoftOx (inneholder også eddik).

\section{Antibiotikaens rolle}

Siden vi snakker om bakterier, er det også viktig å se på rollen til tradisjonelle antibakterielle behandlingsmetoder som antibiotika. Bakteriene i biofilmen er som sagt tolerante for antibakteriell behandling og immunsystemets virkninger. Denne toleransen skyldes i hovedsak fire mekanismer (13, 14):

- Biofilmens «arkitektur», tredimensjonal, med surstoff- og næringsstoffgradienter, «mikromiljø» med forskjellig pH, pCO2 og pO2 som påvirker antibiotika.

- Forskjellige vekstvilkår avhengig av hvor i biofilmen bakteriene er lokalisert.

- Komponenter i matriksen som binder og/eller nøytraliserer antibiotika.

- Pumper som aktivt fjerner antibiotika fra biofilmen. Påvist for eksempel ved forekomst av Pseudomonas-bakterier.

\section{Stafylokokker}

Det er fortsatt nokså vanlig praksis å ta bakterieprøver fra ikke-helende sår. Oftest vil man dyrke frem stafylokokker fra disse sårene. Stafylokokker, som de fleste andre sårpatogener, er biofilmdannere. 


\section{三 «Stafylokokker, som de fleste andre sårpatogener, er biofilmdannere.»}

At et sår med en biofilm fremstår som rødt, hovent, væskende og smertefullt, skyldes imidlertid ikke en klassisk infeksjon, men immunsystemets reaksjon på biofilmen, som vi kaller en inflammasjon. Denne inflammasjonen vil neppe kunne behandles med antibiotika, verken gitt systemisk eller lokalt.

\section{For mye antibiotika}

Det er et betydelig overforbruk av antibiotika i ikkehelende sår (15). Man antar at cirka ti prosent av all forskrivning av antibiotika i Norge handler om bløtvevsinfeksjoner. Unødvendig forskrivning av antibiotika bidrar til resistensproblematikken.

\section{三 «Det er et betydelig overforbruk av antibiotika i ikke-helende sår.»}

Kunnskapen om hvilken rolle biofilmen har i ikkehelende sår, hvilken måte den fungerer på, og hvordan den er organisert, må få som konsekvens at det ikke tas rutinemessig bakterieprøver fra sår. Vi vet at det vanligvis er nytteløst å bruke antibiotika. Antibiotika skal kun gis til pasienter som er systemisk påvirket, og når såret er identifisert som den utløsende faktoren (16).

\section{Konklusjon}

Bakteriell biofilm spiller en rolle i de fleste ikkehelende sår, og det må vi ta hensyn til når vi velger behandlingsstrategier. Det eneste vi vet som virker, er å kombinere debridering med lokale antibakterielle midler, som PHMB (polyhexamethylene biguanide, tørrstoff som benyttes til desinfeksjon), sølv, jod og honning. Såret bør debrideres hver gang det behandles, inntil såret har fått en overflate av granulasjonsvev. Da kan både debridering og bruk av antibakterielle midler avsluttes (7). 
Valg av debrideringsmetode må ta utgangspunkt i hva som er gjennomførbart. Hvis det i prosedyren legges opp til skarp debridering samtidig som de som behandler såret, ikke behersker denne metoden, fører det kun til inkonsekvent behandling og sabotasje av prosedyren. Alternativet er da å kun la personell med kompetanse innen skarp debridering utføre dette sårstellet.

Det er helt avgjørende at såret behandles konsekvent og i henhold til planen. Metode bør også velges avhengig av pasient- og sårrelaterte faktorer. Det er viktig å unngå smerte og ikke påføre sår tilleggsskade.

\section{Sykepleien har utviklet et digitalt verktøy for sårvurdering basert på TIMES:}

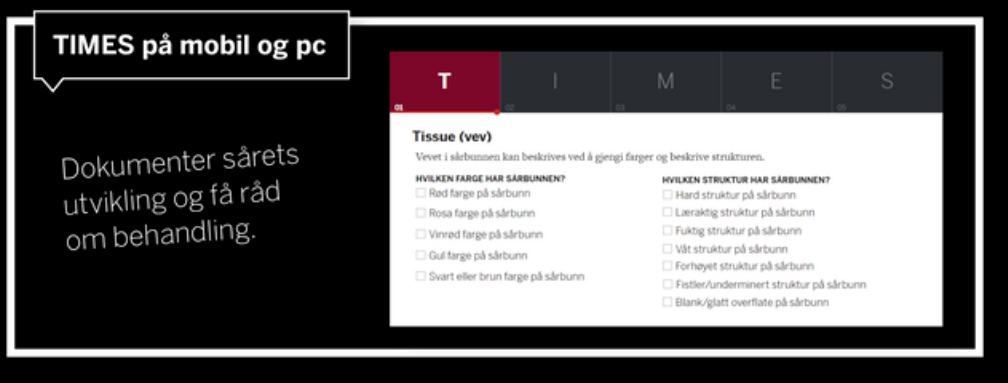

\section{Referanser}

1. World Union of Wound Healing Societies (WUWHS), Florence Congress, Position Document. Wounds international; 2016.

2. Schultz GS, Sibbald RG, Falanga V, Ayello

EA, Dowsett C, Harding K, et al. Wound bed preparation: a systematic approach to wound management. Wound Repair Regen. 2003 Mars; 11 Suppl 1(s1):S1-28.

3. Rhoads DD, Wolcott RD, Percival SL.

Biofilms in wounds: management strategies. J Wound Care. 2008;17(11):502-8.

4. Wolcott RD, Rhoads DD, Dowd SE. Biofilms and chronic wound inflammation. J Wound Care. 2008;17(8):333-41. 
5. Wolcott RD, Rumbaugh KP, James G, Schultz G, Phillips P, Yang Q, et al. Biofilm maturity studies indicate sharp debridement opens a time- dependent therapeutic window. J Wound Care. 2010;19(8):320-8.

6. Malone M, Bjarnsholt T, McBain AJ, James GA, Stoodley P, Leaper D, et al. The prevalence of biofilms in chronic wounds: a systematic review and meta-analysis of published data. J Wound Care. 2017;26(1):20-5.

7. Langøen A, Gürgen M. Sårbehandling, generelle prinsipper. I: Langøen A, red. Sårbehandling og hudpleie. 5 utg. Oslo: Gyldendal Akademisk; 2018. S. 180-293.

8. O'Meara S, Al-Kurdi D, Ologun Y, Martyn-St James L, Richardson R. Antibiotics and antiseptics for venous leg ulcers - Review. Cochrane Database of Systematic Reviews. 2014. Tilgjengelig fra: https://www.cochrane.org/CD003557/WOUNDS_anti biotics-and-antiseptics-to-help-healing-venous-legulcers (nedlastet 30.01.2019).

9. Langøen A. Kjemisk debridering. Sår. 2018;27(1):47-52.

10. Strohal R, Dissemond J, Jordan O’Brien J, Piaggesi A, Rimdeika R, Young T, et al. EWMA document: Debridement. An updated overview and clarification of the principle role of debridement. J Wound Care. 2013;22(1):5.

11. Nagoba BS, Selkar SP, Wadher BJ, Gandhi RC. Acetic acid treatment of pseudomonal wound infections - a review. J Infect Public Health. 2013;6(6):410-5. 
12. Kumara DU, Fernando SS, Kottahachchi J, Dissanayake DM, Athukorala GI, Chandrasiri NS, et al. Evaluation of bactericidal effect of three antiseptics on bacteria isolated from wounds. J Wound Care. 2015;24(1):5-10.

13. Walters MC, Roe F, Bugnicourt A, Franklin MJ, Stewart PS. Contributions of antibiotic penetration, oxygen limitation, and low metabolic activity to tolerance of Pseudomonas aeruginosa biofilm to ciprofloxacin and tobramycin. Anitmicrobial Agents and Chemotherapy. 2003;47(1):317-23.

14. Mulcahy H, Charron-Mazenod L, Lewenza S. Extracellular DNA chelates cations and induces antibiotic resistance in Pseudomonas aeruginosa biofilms. PLoS Pathog. 2008;4(11):e1000213.

15. Gürgen M. Excess use of antibiotics in patients with non-healing ulcers. EWMA Journal. 2014;14(1):17-22.

16. Gottrup F, Apelqvist J, Bjarnsholt T, Cooper R, Moore Z, Peters EJ, et al. EWMA document:

Antimicrobials and non-healing wounds. Evidence, controversies and suggestions. J Wound Care. 2013;22(5 Suppl):S1-89. 